\title{
Critical Success Factors for ERP Projects: Recommendations from a Canadian Exploratory Study
}

\author{
Sreekumar Menon ${ }^{1}$ \\ ${ }^{1}$ Business Technology Leader \& Director R3Synergy Inc., Calgary, Canada \\ Correspondence: Dr. Sreekumar Menon, Business Technology Leader \& Director, R3Synergy Inc., Calgary, \\ Canada. E-mail: ask_menon@yahoo.com
}

Received: November 2, 2019

Accepted: December 8, 2019

Online Published: January 13, 2020

doi:10.5539/ijbm.v15n2p80

URL: https://doi.org/10.5539/ijbm.v15n2p80

\begin{abstract}
This research paper discusses key recommendations for improving future Enterprise Resource Planning (ERP) implementations based on insights from an exploratory qualitative single case study in the Canadian Oil and Gas Industry. The study was conducted using a semi-structured interview guide from twenty participants belonging to four project role groups of senior leaders, project managers, project team members, and business users. The research evoked a comprehensive list of forty-two critical success factors (CSFs) and out of which, top ten CSFs discussed include: Know your data, longer and more integrated testing, utilization of the right people, longer stabilization period (hyper-care), communication, address legal and fiscal requirements, hyper-care must be longer, early buy-in from business, have a Lean Agile program, less customization and more vanilla out of the box, and project must be business-driven and not IT-driven. This study is one of first ERP case studies in the Canadian oil and gas industry and the research recommendations can prove to be beneficial for organizations when undertaking ERP implementations.
\end{abstract}

Keywords: enterprise resource planning (ERP), implementation, exploratory qualitative case study, benefits, critical challenges, critical success factors, Canadian oil and gas, recommendations, strategies

\section{Introduction}

ERP (Enterprise Resource and Planning) is a centralized and integrated enterprise software system (CEIS) (Menon, 2019), which typically comprise of several functional modules including finance, project systems, sales, procurement, production, human resources, customer relationship management etc. that are tightly integrated with all business functions and other connected applications. ERP system allows integration of business processes with shared customer, vendor, and material databases within the organization. This cross-organizational integration of business processes with shared data, can effectively enable the management to take timely and strategic business decisions (Ross \& Vitale, 2006; Menon, 2016 \& 2019).

Enterprise systems are clearly an important phenomenon, and management can draw key benefits gained from ERP system implementation (Menon, 2019). The benefits include cost control, increased response times, best practices, and fully automated processes. Data visibility, improved visibility to management reporting, analysis, and control for the organization are the other benefits of ERP systems (Esteves \& Pastor, 2001; Finney \& Corbett, 2007). It is important to understand the expected project results when making a suitable implementation plan towards the new enterprise system (Finney \& Corbett, 2007). There are several software companies that dominate the ERP market, which include SAP, Oracle, and Microsoft Dynamics. However, all ERP vendors have their own specific implementation methodology and architectural design models. Critical success factors play a key role in vendor selection, implementation, deployment and support.

The Standish Group (2013) study highlighted the fact that fewer than 10\% of ERP implementations are successful, and cost overruns averaged $178 \%$; schedule overruns, $230 \%$; and that implemented functionality could only meet $41 \%$ of the business needs (Momoh, Roy, \& Shehab, 2010). These statistics indicate that ERP implementation projects are far more likely to fail than succeed. The high failure rates demand that organizations pay close attention to the critical success factors during ERP implementations (Peci \& Važan, 2014; Stanciu \& Tinca, 2013). The majority of ERP research studies conducted to date are quantitative in nature, and there is a very limited number of qualitative studies that explore richer and more detailed accounts of the critical challenges in ERP implementations (Mishra \& Mishra, 2011). The current study is important because very few 
ERP implementations in the Canadian oil and gas sector have been documented and researched, unlike similar studies being conducted in the US, EU, and Asian regions (Mishra \& Mishra, 2011; Chen, Law, \& Yang, 2009). Understanding critical success factors will benefit organizations, helping to ensure improved productivity and better project performance in future ERP implementations.

\section{Foundational studies in ERP and Critical Success Factors}

American Production and Inventory Control Society defined ERP as "a method for the effective planning and controlling of all the resources needed to take, make, ship and account for customer orders in a manufacturing, distribution or service company" (Rashid, Hossain, \& Patrick, 2002). Other definitions of ERP include: "One database, one application and a unified interface across the entire enterprise" (Tadjer, 1998); "ERP systems are computer-based systems designed to process an organization's transactions and facilitate integrated and real-time planning, production, and customer response" (O'Leary, 2001).

Organizations need to connect the information supplied by each department into a common entity to remain competitive. There is a strong need for a seamless flow of data within and between functional units to increase efficiency in areas such as procurement, distribution of goods and services, managing stocks, and to help decision making. A capability to obtain the right information at the right time can usher enormous benefits to an organization (Rashid et al., 2002). ERP software systems that emerged in the late 1970s continue to offer large organizations out-of-the-box solutions for complex business needs. ERP systems are not projects that someday end; they are a way of life that require a high degree of alignment between business strategies, informational technology strategies, and organizational processes (Davenport, 1998; Esteves \& Pastor, 2001).

Rockart (1979) was the first author to apply the critical success factor approach in the information systems area. Rockart (1979) defined critical success factors as the limited number of areas in which results, if satisfactory, will ensure the organization's successful competitive performance (Esteves \& Pastor, 2001). These factors are crucial during projects and can ensure successful ERP implementation. There are several important ERP theories including complexity (Menon, Muchnick, Butler, \& Pizur, 2019a), change management, system, and critical success factor theoretical foundations for ERP research. John Rockart developed critical success factor theory as an important concept for information technology. The CSF method helped organizations to specify their own critical information needs. Achieving satisfactory results in the key areas of critical success factors can ensure competitive advantage leading to improved organizational performance. Rockart's theoretical foundation was further improved upon, verified, and validated by other researchers including Holland and Light (1999), Somers and Nelson (2001), Finney and Corbett (2007), Stanciu and Tinca (2013) and more recently Menon (2016). These researchers suggested the importance of critical success factors and its application to ERP project implementation.

Researchers of seminal studies have identified several success factors, which are outlined in Table 1. 
Table 1. Critical Success Factors in ERP Implementation

\begin{tabular}{|c|c|}
\hline Research Study & Critical Success Factors \\
\hline $\begin{array}{l}\text { Holland and Light } \\
\text { (1999) }\end{array}$ & $\begin{array}{l}\text { Strategic: legacy systems, business vision, ERP strategy, top management support, project scheduling and planning. Tactical: } \\
\text { client consultation, software configuration, client acceptance, monitoring and feedback, communication, troubleshooting. }\end{array}$ \\
\hline $\begin{array}{l}\text { Parr and Shanks } \\
(2000)\end{array}$ & $\begin{array}{l}\text { Management support, best people full-time, empowered decision-makers, deliverable dates, champion, vanilla ERP, smaller } \\
\text { scope, definition of scope and goal, balanced team, commitment. }\end{array}$ \\
\hline $\begin{array}{l}\text { Nah, Lau, and } \\
\text { Kuang (2001) }\end{array}$ & $\begin{array}{l}\text { Top management support; business plan and vision; business process re-engineering with minimum customization; project } \\
\text { management; monitoring and evaluation of performance; effective communication; software development, testing, and } \\
\text { trouble-shooting; project champion; appropriate business and IT legacy systems. }\end{array}$ \\
\hline $\begin{array}{l}\text { Somers and Nelson } \\
(2001)\end{array}$ & $\begin{array}{l}\text { Top management support, project champion, user training and education, management of expectations, vendor-customer } \\
\text { partnerships, use of vendor's development tools, careful selection of the appropriate package, project management, } \\
\text { steering committee, use of consultants, minimal customization, data analysis and conversion, business process re-engineering, } \\
\text { defining the architecture, dedicated resources, project team competence, change management, clear goals and objectives, } \\
\text { interdepartmental communication and cooperation, ongoing vendor support. }\end{array}$ \\
\hline $\begin{array}{l}\text { Finney and } \\
\text { Corbett (2007) }\end{array}$ & $\begin{array}{l}\text { Top management commitment and support, visioning and planning, build a test case, project champion, implementation } \\
\text { strategy and timeframe, vanilla ERP, project management, change management, managing cultural change, balanced } \\
\text { team, project team composed of the best and the brightest, communication plan, empowered decision makers, team } \\
\text { morale and motivation, project cost planning and management, BPR and software configuration, legacy system } \\
\text { considerations, IT infrastructure, client consultation, selection of ERP, consultant selection and relationship, training and } \\
\text { job redesign, troubleshooting and crisis management, data conversion and integrity, system testing, post-implementation } \\
\text { evaluation, and analysis of ERP literature. }\end{array}$ \\
\hline
\end{tabular}

Jayaraman and Project management, business process re-engineering, user training and education, technological infrastructure, change and risk Bhatti (2008) management, top management support, effective communication, balanced team, users' involvement, consultants' involvement, clear goals and objectives.

Note. The list is based on the findings on critical success factors from Holland and Light (1999), Parr and Shanks (2000), Nah, Lau, and Kuang (2001), Somers and Nelson (2001), Finney and Corbett (2007), and Jayaraman and Bhatti (2008).

\section{Methodology}

This research used a qualitative exploratory single-case study design to understand perceptions of four project role groups related to ERP implementation. Exploratory case study research investigates a phenomenon by understanding perceptions and is usually focused on a small sample population to arrive at in-depth and rich data (Hewlett, 2005; Yin, 2014). Case studies typically involve small heterogeneous samples, which offer in-depth investigation. Such a case study is an appropriate tool for undertaking research in ERP implementation (Mishra \& Mishra, 2011; Yin, 2009). Characteristics applicable to exploratory case study research were aligned with this study's objectives: enabling deep focus on scope; generating hypotheses rather than testing them; and exploring a heterogeneous population instead of a homogeneous one (Gerring, 2007). This research also involved collecting documentation and archived records for triangulation (Denzin, 2012; Howe, 2012; Nickson, 2014). The case setting used for the current study is a Canadian oil and gas company involved in ERP implementation. The inclusion criteria required that all participants must have experience in ERP project roles and had worked in ERP implementation projects in the Canadian oil and gas industry.

Stratified sampling was used due to the small sample size and the desire to obtain data from each stratum or participant group (Gerring, 2007). Twenty participants were selected using stratified purposive sampling from the case organization. The sample represents four participant project team roles that consisted of three senior leaders, four project managers, six project team members, and seven business users, for a total of 20 subjects. The interview guide questions were compiled based on research for the current study. One of the research questions was: "What recommendations may help to improve ERP implementation in the future?" All interviews were held in a public place and further document review facilitated data triangulation, which provided another source of data beyond the semi-structured interviews (Denzin, 2012; Howe, 2012; Nickson, 2014; Yin, 2009). 
The researcher conducted a total of 20 face-to-face interviews with participants from the four project team role groups. In-person interviews were voice-recorded, and audio files were transcribed. The collected data was entered in NVivo software for data coding and analysis and data analysis was conducted. Further, document review facilitated data triangulation such that it provided another source of data (Denzin, 2012; Jonsen \& Jehn, 2009; Yin, 2009).

\section{Discussion of Results}

The interview responses to the study highlighted 42 recommendations, as outlined in Appendix A. Out of the 42 recommendations, 10 critical success factors were organized based on frequency count and responses from the role groups of senior leader (SL), project manager (PM), project team member (TM) and business user (BU) as shown in Table 2. These include: know your data, longer and more integrated testing, utilization of the right people, longer stabilization period (hyper-care), communication, address legal and fiscal requirements, hyper-care must be longer, early buy-in from business, have a Lean Agile program, less customization and more vanilla out of the box, and project must be business-driven and not IT-driven.

Table 2. Recommendations to improve future ERP implementations as reported by members of the project role groups

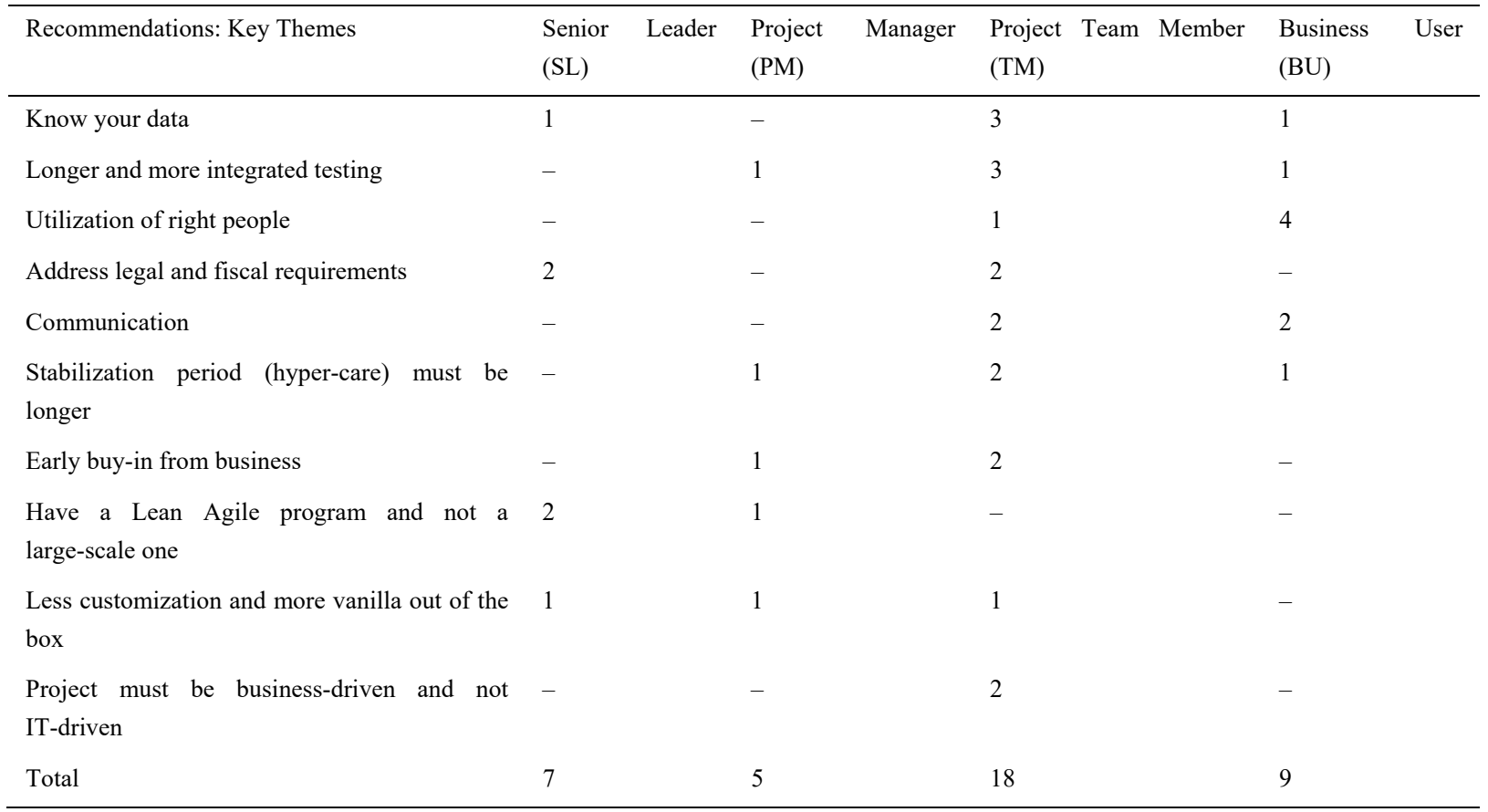

Note. The table highlights top ten recommendations or critical success factors that can be adopted by organizations to improve future ERP implementations. This is based on high-frequency count across all four project role groups. A dash indicates that no member of the group gave this response.

Senior leader (SL) role response highlights. Participant SL1 highlighted the importance of practical experience with the system rather than classroom-based training, and the need to take advantage of past experience from previous implementations. Participant SL2 articulated the need to standardize business models prior to ERP implementation, less customization and more vanilla out of the box solution and understanding the complexity of the company environment. SL3 made a strategic suggestion for future implementation:

I am going to make a statement, whether this is not practical or feasible, I don't know. I think what made the journey particularly challenging for us is that, we were changing everything all at once. You know [pause] ERPs, connected applications, interfaces I mean everything pretty well, you know. And I don't know, if you know that was the most effective means for us to go about making that change in Canada, I don't know. Perhaps it was. But it certainly, it certainly proved to be very, very disruptive. I don't know if something more progressive or 'staged' in the first way of an implementation might have been advisable so when it comes to the ERP, and I know these are highly integrated processes and modules so this may or may not be entirely practical but can you, can you 
actually implement certain elements of the ERP without, you know, going big bang.

Project manager (PM) role response highlights. The project manager role group categorized recommendations, which include the following: secure early buy-in from business, establish scope, have a good project plan, have a Lean Agile program and not a large one, have total understanding of cultural and language differences, and conduct more risk-based testing. Participant PM1 articulated:

What I would do is, would actually, learning in my current role how we were doing things where I worked with a lot of large expensive business platforms in the trading space, what I would do, I would keep the ERP system, pick more vanilla out of the box, so less customizations.

Participant PM2 stated that "my recommendation is to make sure that there is full-time dedicated staff in the project, that's one, [and] secondly [sic], is going back to make sure that there is early buy-in from the business of the new system." Participant PM3 highlighted the importance of proper planning and budgeting to cover the additional resources required for the final go-live. According to PM3:

And then I would think you will need the flexibility that if you saw a great deal of challenges in that month end, then you should extend it to the following month end as well. So now I am saying 5 to 9 -week period, um, would be again ideal.

PM4 stated some of the key facts about Canadian oil and gas sector:

Well I think that, you know, the first thing is there are some legitimate uniqueness within Canada, just because of the fact that it is so cold here in the winter is one thing. The second thing is Canada as a country I think by land mass, it is the second largest county in the world. So a lot of the transportation distances for things are much longer than in other countries, right. Especially when you consider that $90 \%$ of the Canada's population is within 100 miles of the US border and there is a lot more products that's being distributed east to west across east to west coast than in other cases.

Project team member (TM) role response highlights. Project team member TM1 observed that it is important to "avoid customization" and ensure "having the right people in the project," and "realistic timelines" are also crucial.

And then also when it comes to data conversion, you gotta ensure that the level of detail on that data conversion going through it, making sure it's right the first time.

Participant TM2 added that:

In general I would recommend that you don't underestimate the scope of an ERP implementation, hmm, give yourselves lot of time, give yourselves lot of contingency, hmm, it's a big, big change and it's going to touch, like I said it's going to touch your people, it's going to touch your processes, the ways of working are going to be different, and of course this can touch your underlying platforms and your connected applications and all that stuff. So don't underestimate the pain poor-planned implementation can cause. [pauses]

Participant TM3's recommendations included "honestly to understand your data and understand your scenarios and actually do a full test of your scenarios." TM3 also noted the importance of retaining people for an extended period after go-live.

We let go of everybody very quickly, within 6 weeks everybody was gone. So between, I think it was 4 to 6 weeks, we were so worried about the cost of the implementation we got rid of everybody who had any knowledge, em, before we really understood there was an issue.

Participant TM4 highlighted the importance of having "enough resources" for the project, and noted that at the "management level, [a] lot of success depends on meeting targets" and making sure that the project is "green." Participant TM5 observed some of the recommendations as: "So, what I have seen, I think data preparation is crucial. Getting the data ready for migrate on to a new system is one key factor to successful implementation." Another one was "the support from management," and TM5 also advised:

make sure that communication goes to each and every individual down to the lowest level because of the fact that once you have this, once you have this mindset, you can, you will have very minimal if not zero resistance to change.

Participant TM6 commented on the importance of meeting and managing stakeholder expectations, understanding gaps and doing a good gap analysis, and ensuring complete integrated and end-to-end testing. TM6 added:

But from my perspective, it was not a disaster and we got through it and we survived its part of the 
implementation. We can always do better, um, but with the size of teams we had, the expertise we had, like, really it was a huge implementation, or, probably never be part of an implementation this size. So for the size of it, overall it was a great success.

Business user (BU) role response highlights. Participant BU1 highlighted the importance of "knowledge transfer," identifying "gaps as early as possible," and the need to "implement every process before go-live." Participant BU2 stressed the importance of getting the "assistance from the end users from previous launches," "good templates," "stronger focus," "assessing the preparedness," "simulation testing that made relevance to users," and "meet[ing] stakeholder expectations." BU2 provided perspective on the project outcome:

For sure as someone who supported the project, I do believe that we didn't fail, but we didn't meet everybody's expectations right [pause] you know, I, yeah yeah [pause] so and if you would to ask for those of us, for those who are outside of the project, they likely would say it was a failure and I just see it as, okay it just didn't meet expectations, but there is opportunity to continuous improvement, yeah, for sure.

Participant BU3 stressed the importance of "respecting [the] no-fly zone," which is the period of time before and after the implementation in which no changes can be made. Post go-live "stabilization or the hyper-care period must be a minimum of 3 months." BU3's other suggestions were that training must be made mandatory, to solicit volunteers who can help in testing, to focus on the people and focus on the effect that change has on people, and to have people buy in. Participant BU4 provided a few recommendations, which included learning from other implementations, keeping SMEs for a longer period post-implementation, and a longer window for testing. Participant BU5's main recommendations were "getting people involved," having users define how to measure progress, and ensuring that one person not perform multiple roles for the project at the same time. Participant BU6's stated recommendations were to "focus on communication" and "involve everyone so there is no missing process." "Own everything and be responsible for everything" and "have things done at on-site than offshore" were the recommendations from BU7.

\subsection{Theme Highlights}

The importance of data is underscored by the project role group (frequency count five), with its members' statements that can be paraphrased as "know your data." Whether it is data cleansing, preparation, or conversion, it is important to "ensure the level of detail to make sure it is right at the first time" (TM1). Participant SL3 outlined the importance of data as follows:

I think, um, you know data. Data is a terribly important part of this type of transition. Especially if you going from one platform to another, and you know you have in your business some people that are very, very knowledgeable about your existing data structure. Um, helping those people gain an understanding and early understanding [of] what their data structure look[s] like, I think may be worth investing that time and energy so that they can better plan.

Longer and more integrated testing is another recommendation for future implementations. Participant TM3 laid out the need for more focused and integrated testing:

Understand your scenarios and actually do a full test [integrated] of your scenarios, and not, and not. I think that was one of our issues is [that] we didn't test our scenarios as thoroughly as we should have. Hm, an end-to-end test of the scenario would be great.

Utilization of the right people is another recommendation. Participant BU1 stated its importance by saying that the project "need[s] to have right teams in place, at the right times." Another business user, BU5, advised: "get the people that know your business, not just as the focal point" and "make sure that they are being heard and responding to what's coming up, it is the utilization of the right people, [at right] time, [and] at the right place. Hmm and getting them more involved." Addressing legal and fiscal requirements was emphasized by participants and can be considered specific to the Canadian oil and gas industry. However, legal and fiscal rules can be distinct for all countries due to their own unique business rules and regulations. Participant SL2 suggested:

From a Canadian implementation, I think the understanding of the legal, fiscal environments you are working on is critical, and making sure that the solutions you got have been well thought through to address those legal and fiscal requirements perfectly.

Participants BU2, BU6, TM2, and TM5 remarked on the importance of communication. Participant TM5 maintained that the "key [is] in making sure that communication goes to each and every individual down to the lowest level." Another key recommendation from participants was the suggestion of a longer stabilization or hyper-care period. Participant BU3 asserted: 
Six weeks is not good enough for stabilization, 3 months is needed for stabilization. You know, just plan for that; know it, believe it, and make sure that the top leaders know it too. You know that they really need it. When they say we are going to respect this, they actually mean and they are not going to come to a meeting later and say, oh you know, what can we do to make this work.

One key to successful implementation is to obtain early buy-in from the business. Participant PM2 observed that "early buy-in from the business of the new system [is required]. Ensuring that [stakeholders] fully understand what the system will be able to help them, having buy-in is critical." Another participant recommendation for future implementations was to have a Lean Agile program, and not a large-scale one. Participant PM1 commented:

I would not do a large-scale program any more, like we were doing, like we have been doing all the last years, I did [it] with a small group of experts and we do it in a more Lean Agile way together with the business.

Less customization and more vanilla out of box were also regarded as important for future implementation success (PM1, SL2, and TM1). Senior leader SL2 remarked:

One thing about ERP implementation, is the more vanilla standard you can be, the smoother it goes. So you take SAP out of the box, and implement it without trying to modify it, it will be much more successful.

The final highlighted theme in the recommendation category was that the project must be business-driven and not IT-driven. Participant TM1 observed that it is better "having the business really, not just driven by an IT project, but also having the business in every stage of the project." Participant TM2 supported the argument by stating that:

I would, and I said this before; this got to be a business-led thing. So again, these systems are so key and they are so central, and the business has to be; it has to be a business-sponsored change and has to be a business-driven change.

The documentation review found specific mention of legal and fiscal requirements as one of the key scope items for Canada in weekly team meeting template. The template for data conversation gave clear timelines on the process to be followed while executing data conversions; "knowing your data" as a holistic process was not noted in any of the documentation. In triangulating responses, it was noted that all the leading themes were evenly discussed by at least three of the participant role groups. The top response of "knowing your data" was found to be comparatively high, with five out of 20 participants $(25 \%)$ indicating the importance of data in ERP implementation (see Tables 2,3, Figure,1).

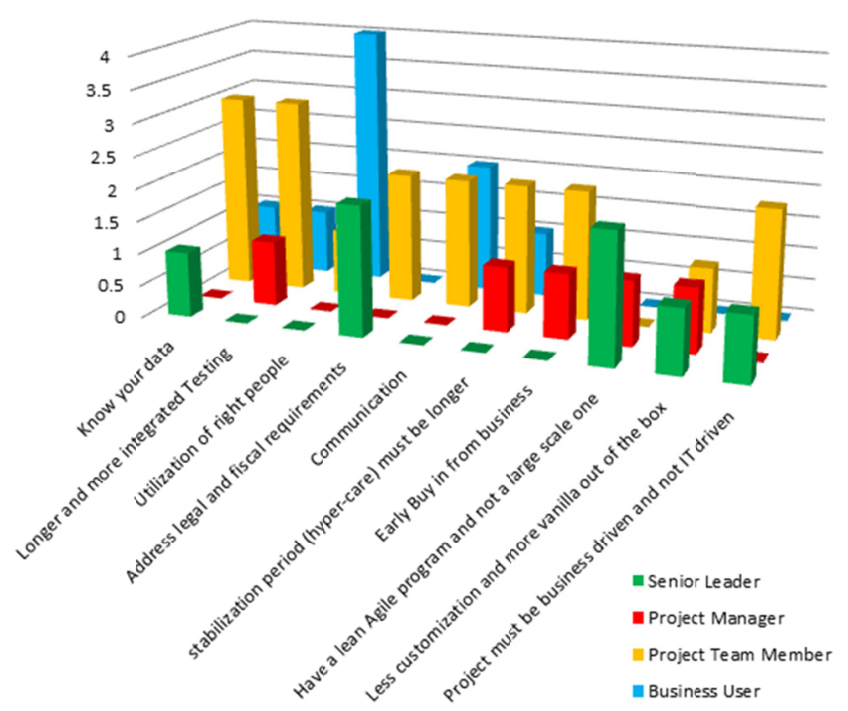

Figure 1. Recommendations for future implementations, as answered by members of the four project role groups

Longer and more integrated testing and utilization of the right people also yielded responses from $25 \%$ of participants, making these recommendations noteworthy. The recommendation to have a Lean Agile program and not a large-scale one garnered support from senior leader and project manager role groups. Another key recommendation, that the project must be business-driven and not IT-driven, received responses only from the 
project team member role group. The researcher was surprised by the large number of recommendations (42 in total, see Appendix A) from participant responses related to future implementation. However, the top 10 recommendations aligned to critical success factors introduced new ideas for the success of future ERP implementations.

\subsection{Implications of Critical Success Factors}

Critical success factors: know your data, less customization and more vanilla out of the box, communication, and utilization of the right people were discussed in literature (Finney \& Corbett, 2007; Holland \& Light, 1999; Jayaraman \& Bhatti, 2008; Nah, Lau, \& Kuang 2001; Parr \& Shanks, 2000; Shaul \& Tauber, 2013; Somers \& Nelson, 2001). Testing is mentioned in literature (Aladwani, 2001; Finney \& Corbett, 2007; Nah et al., 2001); however, the literature did not mention the current study's specific recommendations: longer and more integrated testing, a Lean Agile program, and early buy-in from the business.

Know your data. First, "know your data" is an extremely important critical success factor as described by SL3:

Especially if you [are] going from one platform to another and you know you have in your business some people that are very, very knowledgeable about your existing data structure, um, helping those people gain an understanding, an early understanding [of] what their data structure look[s] like, I think, may be worth investing that time and energy.

"Knowing your data" is an important recommendation that can overcome critical challenges in ERP implementations (Menon, 2016).

Table 3. Themes on recommendations

\begin{tabular}{ll}
\hline Themes on Recommendations & Literature \\
\hline Know your data & $\begin{array}{l}\text { Doom, Milis, Poelmans \& Bloemen, 2010; Finney \& } \\
\text { Corbett, 2007; Somers \& Nelson, 2001 }\end{array}$ \\
$\begin{array}{l}\text { Longer and more integrated testing } \\
\text { Utilization of right people }\end{array}$ & $\begin{array}{l}\text { Parr \& Shanks, 2000; Tsai, Shaw, Fan, Liu, Lee, \& Chen } \\
\text { Address legal and fiscal requirements }\end{array}$ \\
Communication & 2010 \\
& Holland \& Light, 1999; Nah et al., 2001; Jayaraman and \\
Stabilization period (hyper-care) must be longer & Bhatti, 2008 \\
Early buy-in from business & - \\
Have a Lean Agile program and not a large-scale one & - \\
Less customization and more vanilla out of the box & - \\
Project must be business-driven and not IT-driven & Somers \& Nelson (2001) \\
\hline
\end{tabular}

"What recommendations may help to improve ERP implementation in the future?" Themes on critical success factors are based on highest frequency count. Literature is the corresponding research literature. A dash indicates that the theme was not found in the literature.

Longer and more integrated testing. Longer and more integrated testing is the second critical success factor that emerged from the participants' responses. Participant TM6 gave the perspective clearly: "making sure that users understand it end-to-end and you do an integrated testing" and TM3 echoed, "test the scenarios thoroughly from an end-to-end perspective." The implication of this theme is that longer and more integrated testing is an important recommendation that can overcome critical challenges in ERP implementations (Menon, 2016; Menon, Muchnick, Butler, \& Pizur, 2019b) and supports the existing literature on testing (Aladwani, 2001; Finney \& Corbett, 2007; Nah et al., 2001); however, there was no specific mention in literature on longer and more integrated testing.

Utilization of right people. The third critical success factor was that the project must adopt what BU5 called "utilization of right people." Participant BU5 further explained that an ERP implementation's success requires that the company "get the people that know your business" and that it agree to "utilization of the right people [at the] time at the right place." "Utilization of the right people" is an important recommendation that can overcome critical challenges in ERP implementations (Menon, 2016).

Address legal and fiscal requirements. The fourth critical success factor was to "address legal and fiscal 
requirements." Although this came out as a Canadian scope item, the impact is for all implementations and therefore it is relevant as a general recommendation. Participant SL3 noted:

You want to make sure and you want to pay attention to this, that, that the tools and the processes are going to effectively work [and] realize when it is too late, you can't transact in Canadian currency or you can't transact in appropriate unit of measure whether be cubic meters versus barrels and so forth.

Communication. The fifth critical success factor stressed the importance of "communication." Participant TM5 underscored the importance of "making sure that communication goes to each and every individual down to the lowest level," and TM2 said, "as much as possible, clearly communicate the winds for people." The implication of this critical success factor is that effective and thorough communication is an important recommendation that can overcome critical challenges in ERP implementations and supports the existing literature (Holland \& Light, 1999; Nah et al., 2001; Jayaraman and Bhatti, 2008; Menon, 2016).

Longer stabilization period (hyper-care). The sixth recommendation that emerged from the interviews was that the stabilization period (hyper-care) must be longer. According to participant BU3, "6 weeks is not good enough for stabilization, 3 months is needed for stabilization," and TM2 recommended a "longer hyper-care period where the business is actually using tools, where the actual reality [sic] as opposed to something that is theoretical." An extended period of hyper-care is an important recommendation that can overcome critical challenges in ERP implementations (Menon, 2016).

Early buy-in from business. The seventh critical success factor was to get early buy-in from business; PM2 stated that this can be addressed by "ensuring that [stakeholders] fully understand what the system will be able to help them [sic], [and] having buy-in is critical." The implication of this recommendation is that obtaining early buy-in from business can help overcome critical challenges in ERP implementations (Menon, 2016).

Having a Lean Agile program. Having a Lean Agile program and not a large-scale one was recommended by PM1, who explained, "I would not do a large-scale program any more, [in the future] I [would do] with a small group of experts, and we do it in a more Lean Agile way together with the business." Lean Agile program, as opposed to a large-scale one, is a highly useful recommendation and critical success factor.

Less customization and more vanilla out-of-box. The ninth success factor highlighted the importance of "less customization and more vanilla out-of-box implementation." Participant SL2 stated, "One thing about ERP implementation is the more vanilla standard you can be, the smoother it goes [and] so you take SAP out of the box and implement it without trying to modify it, it will be much more successful."

Project must be business-driven and not IT-driven. The tenth and final of the key recommendations was that the "project must be business-driven and not IT-driven." Participant TM2 explained: "[ERP implementation] got to be a business-led thing. So again, these systems are so key and they are so central, and the business has to be; it has to be a business-sponsored change, and has to be a business-driven change." ERP implementation project should be always business-driven, and IT should only assist the business in supporting various project goals set by the organization.

These recommendations highlighted the CSF method, which organizations could apply in order to specify their own information needs on critical issues and to improve future ERP implementations (Dezdar, 2012; Finney \& Corbett, 2007; Moohebat, Jazi, \& Asemi, 2011; Shaul \& Tauber, 2013). New recommendations from the top 10 (Tables 2, 3; Figure 1) along with the full list of 42 recommendations (Appendix A) can be used for future research. Considering the large number of 42 recommendations generated from the study (Appendix A), the possibility of future research for all recommendations not listed in the existing literature must be explored.

\section{Conclusion}

While the study produced forty-two critical success factors (CSFs) only top ten CSFs were discussed, which include: Know your data, longer and more integrated testing, utilization of the right people, longer stabilization period (hyper-care), communication, address legal and fiscal requirements, hyper-care must be longer, early buy-in from business, have a Lean Agile program, less customization and more vanilla out of the box, and project must be business-driven and not IT-driven. Exploration in success factor field has enabled researchers to identify success factors that are critical to ERP project success. One of the implications of this ERP study is that it is conducted in industry area of Canadian oil and gas sector. If this study were to be replicated, it would be necessary to add two separate groups one for IT leader group and a second one for the business leader group, instead of a general senior leader group. This will enable to get the senior leadership perspective from both IT and business (Menon, 2016). 
ERP system chosen for this research study is SAP, since the case organization has implemented SAP system. A similar study can choose another ERP system such as Oracle or Microsoft Dynamics ERP to arrive at the results. Also, instead of the current qualitative methodology, future research can use a quantitative, descriptive, non -experimental design using surveys across multiple organizations to support current study findings (Denzin \& Lincoln, 2008). Another future study recommendation is to conduct a multiple case study that could use two or more organizations so that similar or contrasting results could be predicted (Menon, 2019; Menon, 2016; Menon et al., 2019b; Yin, 2014)

Addressing critical success factors in ERP implementation can help overcome challenges faced by organizations. ERP literature has identified critical success factors based on several studies and specifically, the current study explored and compiled a comprehensive list of critical success factors that can affect ERP project implementations. This guide can prevent organizations from making costly mistakes and the effective application of CSFs can ensure project success and reduce failures during ERP implementations.

\section{References}

Aladwani, A. M. (2001). Change management strategies for successful ERP implementation. Business Process Management Journal, 7, 266-275. https://doi.org/10.1108/14637150110392764

Chen, C., Law, C., \& Yang, S. (2009). Managing ERP implementation failure: A project management perspective. IEEE Transactions on Engineering Management IEEE Trans. Eng. Manage., 56, 157-170. https://doi.org/10.1109/tem.2008.2009802

Davenport, T. H. (1998). Putting the enterprise into the enterprise system. Harvard Business Review, 76(4), 121-131.

Denzin, N. (2012). Triangulation 2.0. Journal of Mixed Methods Research, 6(2), 80-88. https://doi.org/10.1177/1558689812437186

Denzin, N. K., \& Lincoln, Y. S. (2008). Strategies of qualitative inquiry (3rd ed.). Thousand Oaks, CA: Sage.

Dezdar, S. (2012). Strategic and tactical factors for successful ERP projects: Insights from an Asian country. Management Research Review, 35(11), 1070-1087. https://doi.org/10.1108/01409171211276945

Doom, C., Milis, K., Poelmans, S., \& Bloemen, E. (2010). Critical success factors for ERP implementations in Belgian SMEs. Journal of Enterprise Information Management, 23(3), 378-406. https://doi.org/10.1108/17410391011036120

Esteves, J, M., \& Pastor J. A., (2001). Analysis of critical success factors relevance along SAP implementation phases. Proceedings of Seventh Americas Conference on Information Systems, USA. Retrieved from http://aisel.aisnet.org/cgi/viewcontent.cgi?article=1636\&context=amcis2001

Finney, S., \& Corbett, M., (2007). ERP implementation: A compilation and analysis of critical success factors. Business Process Management Journal, 13(3), 329 -347. https://doi.org/10.1108/14637150710752272

Gerring, J. (2007). Case study research: Principles and practices (1st ed.). Cambridge, UK: Cambridge University.

Hewlett, A. K. (2005). Constructive thinking from theory to practice: An exploratory study (Doctoral dissertation). Retrieved from ProQuest Dissertations and Theses database. (UMI No. NR08783)

Holland, P. C., \& Light, B. (1999). A critical success factors model for ERP implementation. IEEE Software (16)3, 30-36. https://doi.org/10.1109/52.765784

Howe, K. (2012). Mixed methods, triangulation, and causal explanation. Journal of Mixed Methods Research, 6, 89-96. https://doi.org/10.1177/1558689812437187

Jayaraman, V., \& Bhatti, T. (2008). The critical success factors for the acquisition and implementation of ERP systems. Paper presented at the International DSI / Asia and Pacific DSI 2007, Bangkok, Thailand. Retrieved from http://iceb.nccu.edu.tw/proceedings/APDSI/2007/papers/Final_27.pdf

Jonsen, K., \& Jehn, K. A. (2009). Using triangulation to validate themes in qualitative studies. Qualitative Research in Organizations and Management: An International Journal, 4, 123-150. https://doi.org/10.1108/17465640910978391

Menon, S. (2019). Benefits and Process Improvements for ERP Implementation: Results from an Exploratory Case Study. International Business Research, 12(8), 124-132. https://doi.org/10.5539/ibr.v12n8p124 
Menon, S. A. (2016). Critical challenges in ERP implementation: A qualitative case study in the Canadian oil and gas industry (Doctoral dissertation). Retrieved from ProQuest Dissertations \& Theses. Capella University, Minneapolis, US. (Accession order No. AAT 10252616)

Menon, S. A., Muchnick, M., Butler, C., \& Pizur, T. (2019a). Complexity Theory: Insights from a Canadian ERP Project Implementation. International Journal of Business and Management, 14(6), 84-98. https://doi.org/10.5539/ijbm.v14n6p84

Menon, S. A., Muchnick, M., Butler, C., \& Pizur, T. (2019b). Critical Challenges in Enterprise Resource Planning (ERP) Implementation. International Journal of Business and Management, 14(7), 54-69. https://doi.org/10.5539/ijbm.v14n7p54

Mishra, A., \& Mishra, D. (2011). ERP System implementation: Evidence from the oil and gas sector. Acta Polytechnica Hungarica, 8(4),416-428.

Momoh, A., Roy, R., \& Shehab, E. (2010). Challenges in enterprise resource planning implementation: State-ofthe-art. Business Process Management Journal, 4, 537-565. https://doi.org/10.1108/14637151011065919

Moohebat, M. R., Jazi, M. D., \& Asemi, A. (2011). Evaluation of the ERP implementation at Esfahan Steel Company based on five critical success factors: A case study. International Journal of Business and Management, 6(5). https://doi.org/10.5539/ijbm.v6n5p236

Nah, F. F., Lau, J. L., \& Kuang, J. (2001). Critical factors for successful implementation of enterprise systems. Business Process Management Journal, 7, 285-296. https://doi.org/10.1108/14637150110392782

Nickson, A. (2014). A qualitative case study exploring the nature of new managerialism in UK higher education and its impact on individual academics' experience of doing research. Journal of Research Administration, 45(1), 47-80.

O'Leary, D. E. (2000). Enterprise resource planning systems: Systems, life cycle, electronic commerce, and risk. Cambridge, UK: Cambridge University.

Parr, A., \& Shanks, G. (2000). A model of ERP project implementation. Journal of information technology, 15(4), 289-303.

Peci, M., \& Važan, P. (2014). The biggest critical failure factors in ERP implementation. Applied Mechanics and Materials, 519-520, 1476-1480. https://doi.org/10.4028/www.scientific.net/amm.519-520.1476

Rashid, M. A., Hossain, L., \& Patrick, J. D. (2002). The evolution of ERP systems. Enterprise Resource Planning: Global Opportunities and Challenges, 1-16. https://doi.org/10.4018/978-1-931777-06-3.ch001

Rockart, J. F. (1979). Chief executives define their own needs. Harvard Business Review, 81-93.

Ross, J.W., \& Vitale, M, R. (2000). The ERP revolution: Surviving versus thriving. Information Systems Frontiers, 2(2), 233-241. Retrieved from http://link.springer.com/journal/10796

Shaul, L., \& Tauber, D. (2013). Critical success factors in enterprise resource planning systems. ACM Computing Surveys, 45(4), 1-39. https://doi.org/10.1145/2501654.2501669

Somers, T. M., \& Nelson, K. (2001). The impact of critical success factors across the stages of enterprise resource and planning implementations. Proceedings of the 34th Hawaii International Conference on System Sciences, USA, 105, 1-10. https://doi.org/10.1109/HICSS.2001.927129

Stanciu, V., \& Tinca, A. (2013). ERP solutions between success and failure. Accounting \& Management Information Systems, 12(4), 626-649.

Standish Group, The. (2013). Chaos Manifesto 2013. Retrieved from http://www.versionone.com/assets/img/files/CHAOSManifesto2013.pdf

Tadjer, R. (1998, April 13). Enterprise Resource Planning. Internet Week, Manhasset.

Tsai, W., Shaw, M., Fan, Y., Liu, J., Lee, K. C., \& Chen, H. C. (2010). An empirical investigation of the impacts of internal/external facilitators on the project success of ERP: A structural equation model. Decision Support Systems, 50(2), 480-490.

Yin, R. K. (2009). Case study research: Design and methods (4th ed.). Thousand Oaks, CA: Sage.

Yin, R. K. (2014). Case study research: Design and methods (5th ed.). Los Angeles, CA: Sage. 
Appendix A. Full List of recommendations to improve future ERP implementations

\begin{tabular}{|c|c|c|c|c|}
\hline Recommendations to improve future ERP implementations & $\begin{array}{l}\text { Senior } \\
\text { Leader }\end{array}$ & $\begin{array}{l}\text { Project } \\
\text { Manager }\end{array}$ & $\begin{array}{l}\text { Project Team } \\
\text { Member }\end{array}$ & $\begin{array}{l}\text { Business } \\
\text { User }\end{array}$ \\
\hline Address legal and fiscal requirements & 2 & - & 2 & - \\
\hline Ask for volunteers for testing & - & - & - & 1 \\
\hline Assess the project preparedness & - & - & - & 1 \\
\hline Better alignment of business with processes & 1 & - & - & - \\
\hline Better integration & - & 1 & 1 & - \\
\hline Communication & - & - & 2 & 2 \\
\hline Do not underestimate the disruptions & 1 & 1 & - & - \\
\hline Early buy-in from business & - & 1 & 2 & - \\
\hline Establish scope and the fit of the solution & - & 1 & 1 & - \\
\hline Execute relevance test simulations & - & - & 1 & 1 \\
\hline Full-time dedicated staff without multiple roles & - & 1 & - & 1 \\
\hline Good project plan & - & 1 & - & - \\
\hline Have a Lean Agile program and not a large-scale one & 2 & 1 & - & - \\
\hline Have a detailed gap analysis & - & - & 1 & - \\
\hline Have things done at on-site than offshore & - & - & - & 2 \\
\hline Identify gaps as early as possible & - & - & - & 1 \\
\hline Implement every process before go-live & - & - & - & 1 \\
\hline Keep the established dispute process & 1 & - & - & - \\
\hline Know your data & 1 & - & 3 & 1 \\
\hline Knowledge transfer & 1 & - & 1 & 1 \\
\hline Leadership commitment must be aligned with the organization & 1 & - & - & - \\
\hline Learning from other implementations & 1 & - & - & 2 \\
\hline $\begin{array}{l}\text { Less classroom-type learning and more practical experience with } \\
\text { system }\end{array}$ & 1 & - & - & - \\
\hline Less customization and more vanilla out of the box & 1 & 1 & 1 & - \\
\hline Longer and more integrated testing & 0 & 1 & 3 & 1 \\
\hline Make training mandatory and have timely targeted training & 1 & - & - & 1 \\
\hline Manage people change & - & - & 2 & 1 \\
\hline Manage people stress & - & - & 1 & - \\
\hline Manage stakeholders & - & - & 1 & - \\
\hline Meet stakeholder expectations & - & - & 1 & 1 \\
\hline Move to cloud-based solutions & 1 & - & - & - \\
\hline Need good templates in place & - & - & 0 & 1 \\
\hline Project must be business-driven and not IT-driven & - & - & 2 & - \\
\hline Respect no-fly zone & - & - & - & 1 \\
\hline Retain SMEs for longer period post-implementation & - & - & - & 1 \\
\hline Stabilization period (hyper-care) must be longer & - & 1 & 2 & 1 \\
\hline Stronger focal point or super users & - & - & - & 1 \\
\hline Total understanding of cultural and language differences & - & 1 & 1 & - \\
\hline Try to avoid "us versus them" mentality & - & - & - & 1 \\
\hline Undertake more risk-based testing & - & 1 & - & - \\
\hline Users must define own KPIs & - & - & - & 1 \\
\hline Utilization of right people & - & - & 1 & 4 \\
\hline Total & 15 & 12 & 29 & 29 \\
\hline
\end{tabular}

Note. The table shows all 42 recommendations that can be used to improve future ERP implementations. This is based on high-frequency count across all four project role groups. A dash indicates that no member of the group made the recommendation.

\section{Copyrights}

Copyright for this article is retained by the author(s), with first publication rights granted to the journal.

This is an open-access article distributed under the terms and conditions of the Creative Commons Attribution license (http://creativecommons.org/licenses/by/4.0/). 